\title{
LECTURER PERFORMANCE DECISION SUPPORT SYSTEM USING THE TOPSIS METHOD BASED ON WEB
}

\author{
Suandi Daulay \\ Sekolah Tinggi Teknologi Pekanbaru, Indonesia \\ suwandidaulay90@gmail.com
}

Received : 20 November 2020, Revised: 20 Desember 2020, Accepted : 21 December 2020

\begin{abstract}
AMIK Mahaputra is one of the private computer colleges in the city of Pekanbaru. In increasing its resources, this university conducts performance appraisals of lecturers and employees. This performance assessment will form the basis of promotion. At present, the system in assessing its performance still has weaknesses, namely by improper lecturers or employees who occupy certain positions and positions. The purpose of this study is to later be able to make it easier to give a decision on the performance evaluation of lecturers and employees each year as part of the process of career development and promotion. The data obtained include the assessment of lecturers by students, the discipline of lecturers on giving lectures, the allocation of time by each lecturer and the method used is TOPSIS where this method is considered suitable for this research. and AMIK employees Mahaputra pekanbaru. Decision support system for evaluating the performance of lecturers and employees in promotion. Although the decision taken has been $74 \%$ but it has been recommended to assist the management of AMIK Mahaputra in making decisions.
\end{abstract}

Keywords : Decision Support System, TOPSIS, Lecturer Performance

\section{Introduction}

Institutions that move dynamically require harmonious human resource relationships, with the role of organizational communication being very important. The formal authority of a manager causes the emergence of three roles in the communication between personality, information roles and deciding roles. The university management paradigm has been transformed from the power of science to an institution that provides information, which is not limited to space and time, with the presence of powerful media forms from information technology to teaching and research networks. Higher education is an organization that is highly dependent on the performance of its members' human resources, in this case, including lecturers as part of the available resources.

Universities must recognize the importance of human resource development. The role of the duties and responsibilities of lecturers is very important in achieving the goals of national education, namely the intellectual life of the nation, improving the quality of Indonesian people, including the quality of faith, piety, character, mastery of science, technology, and art, and to bring Indonesians forward, fair, prosperous, and civilized (Tahir et. al., 2017). Lecturers as the main resource in presenting high quality education. Improving the quality of faculty performance is a complex problem faced by many universities in Indonesia. Performance measurement and quality assessment of lecturers are usually measured by three main indicators, namely education and teaching, research and community service. The third indicator is known as the university's Tri Dharma. Overall so as to produce a complete performance assessment according to many relevant indicators. In addition, the leadership factor in an organization is rarely included as an indicator that is also able to boost lecturer performance (Suryaman, 2018).

The university is one of the educational institutions that produces quality human resources. Government Regulation No. 30/1990 explains that universities are aimed at preparing citizen students who have academic or professional abilities who can apply, develop, and create science, technology, and arts. There are several struggles to achieve the dream of appearing in quality higher education. There needs to be major improvements to its aspects, lecturers are the most important aspect to improve the quality of tertiary education. High lecturer performance affects the quality of higher education. This study aims to determine the factors that affect lecturer performance. Lecturer performance factors include experience, skills, age, gender, education, 
tenure, responsibility, job satisfaction, perceptions, motivation, leadership, costs, supervision, and working conditions (Hadiantini, et. al., 2017).

Kennedy, D., 1997, according to him that the main task of lecturers' academic tasks is apart from teaching, but they must also be able to find and publish their findings. Scientific publications in the reputation of national and international journals, act as self-actualization media for academics and researchers in the development of science internationally. But in general, the performance of lecturers' scientific publications in Indonesia is still far behind including the citation index compared to the scientific publications of lecturers in Southeast Asian countries (Lubis, et al, 2018).

\section{Literature Review}

Decision making is the main management activity which greatly determines the existence of an organization. Errors in decision making can have fatal consequences for an organization. Because this activity is very important, management experts are always looking for systems, methods and technology that can assist management in carrying out these tasks. In line with the development of information technology, various management support systems were developed including computer-based Decision Support Systems. This system is a computer-based system designed to increase the effectiveness of decision makers in solving semi-structured or unstructured problems(Irawan, 2020).

Lecturers are academic staff in charge of implementing the Tridarma of higher education, which includes education and teaching, research and development of science and technology and community service as well as supporting activities. The purpose of selecting outstanding lecturers is to provide real and extraordinary recognition of lecturers for conducting university Tridharma activities whose results can be proud of and are very beneficial for the progress of improving academic and institutional quality(Azizu \& Sari, 2020).

According to Mufizar (2016) Decision Support System (SPK) / Decision Support System is an intelligent system that includes a knowledge-based system to support decision-making activities quickly and precisely. DSS uses data, provides an easy-to-use interface, and allows decision makers to use insights on their own. According to Surya (2018) Decision Support System (DSS) / Decision Support System is a process of choosing between various alternatives, managerial decision making is synonymous with the overall process of management Decision support system can be defined as a system intended to support managerial decision makers in situations unstructured decisions. Damanik \& Bangun (2018) Decision Support System (DSS) can be defined as a computer program that provides information in the application domain provided by a decision analysis model and access to a database, where it is intended to support decision makers (Decision Maker) in make decisions effectively in both complex and unstructured conditions. The decision making system is an inseparable part of the totality of the entire organizational system. That the organizational system includes at least operational systems, decision systems, and information systems.

One method that can be used for decision support is the TOPSIS method. The TOPSIS method is a method of assessment that can be interpreted as giving each object its specific value to be evaluated(Rahim, et. al., 2018). The TOPSIS method is a simple and efficient multiple criteria method for identifying solutions from a set of several alternatives(Muslihudin, et. al., 2019). The decision support system for the recommendation for graduation of thesis trial student participants using AHP-TOPSIS has been produced. This DSS can provide accuracy based on the Hamming distance of $96.2 \%$ and the Euclidean distance of 0.8096 for 95 sample student data between 2014-2016 so that it can be applied to recommend the graduation of student participants for the thesis trial(Sari, et.al., 2018).

\section{Research Methods}

Research activities are activities in solving a problem which is expected to obtain the desired results and in a long enough time by applying scientific methods based on the procedures and rules that are enforced. In a study, a methodology that contains a framework is needed. Where in this framework in the form of a description of the steps to be carried out so that the research can run systematically and the objectives that are expected to be achieved as desired. The 
framework of thought is usually in the form of a theoretical framework and a logical pattern of reasoning framework. The theoretical framework in question is a summary description of the theory used and how to use the theory in answering the research questions. Framework is a writing plan that draws an outline of an essay to be worked on, as well as a series of several ideas that will be arranged in a systematic, logical, clear, orderly and structured manner. This chapter will describe the research framework, in which this framework is the steps that will be taken in solving problems that are the main subject of discussion. Where this research framework can be seen in Figure below:

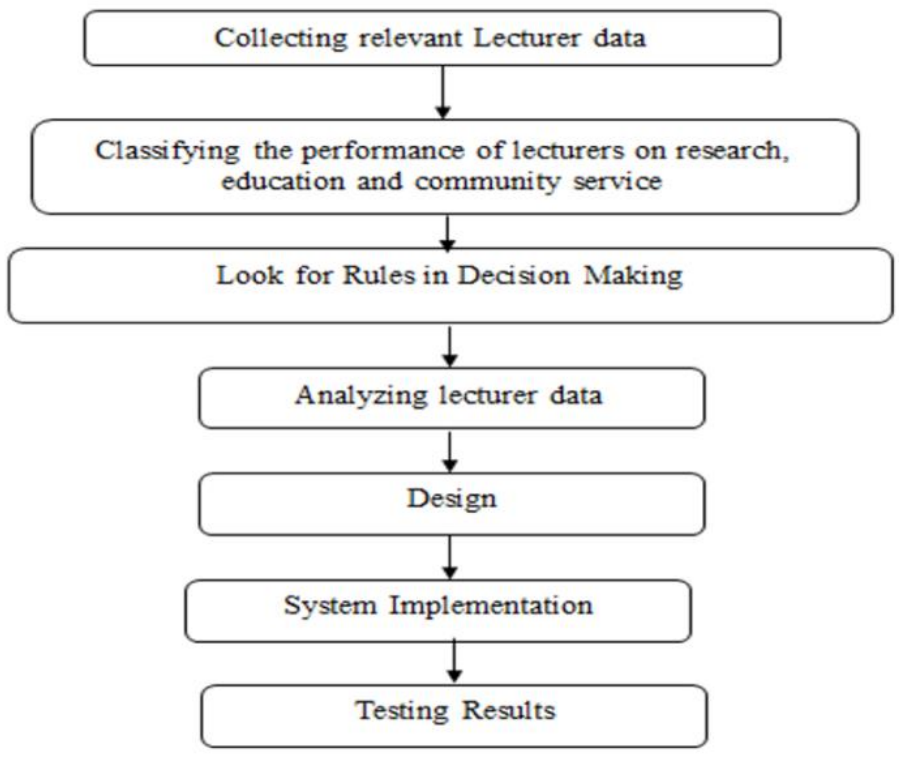

1. Relevant Lecturer Data

Figure 1. Research Framework

In this stage the writer collects data which comes from related problems. Where the data obtained from Amik MahaPutra Pekanbaru. These data are in the form of research, education and service.

2. Grouping data about lecturer performance.

In this step, the process of grouping research data is carried out using two methods, namely:

a. Descriptive method in which data is collected, then arranged, grouped and analyzed, so as to obtain some clear picture results on the problems to be discussed.

b. Comparative Method in which analysis is carried out by comparing theory and practice, so as to obtain a clear picture of the similarities and differences between the two.

3. Look for Rules in Decision Making

Where the search for rules is in accordance with the basis of complete knowledge into separate elements in the form of criteria where later this criterion can solve problems with facts with existing knowledge.

4. Analyzing Lecturer Data

The data obtained will then be analyzed in order to produce useful information in determining the performance of lecturers in data analysis using the TOPSIS method. This method is expected to produce solutions from the lecturer's performance.

5. Design

To meet the needs of Amik Mahaputra Pekanbaru as a system user, the system design stage was carried out. System design in this step begins by presenting data in the form of criteria which are managed using the TOPSIS method, design input interfaces, creating algorithms and creating interface outputs. At the system design stage, the design is carried out using UML (Unified Modelling Language).

6. Implementation of the system 
In the implementation phase of the system, the coding process or application creation is carried out. In this research, the application development will be built using Hypertext Preprocessor (PHP) by applying the TOPSIS method(Zyoud \& Fuchs-Hanusch, 2017)

\section{Results and Discussions}

Determination of lecturer performance based on existing criteria. There are several criteria that need to be considered in determining the performance of lecturers, namely: Education, Research, Community Service, Responsibility, Personality, Loyalty, Cooperation, and Leadership.

After the alternatives and criteria are determined, the weighting of the scores for each criterion is carried out for each alternative. The next step is to carry out an analysis process of the results obtained from data processing. The results or outputs from processing are information in the form of priority values from the alternative performance of the lecturers that have the highest to the lowest scores. This information will certainly be used by the decision maker in making decisions.

In designing this decision support system, supporting data is needed, including: Alternative data and Criteria data. Alternative data consists of data from alternative lecturers to be tested, namely: Julianto Simatupang, Mukhtar Muhammad, Sinta Maria and Fitri Ayu.

The criteria data consist of the three dharma colleges of the lecturer, the criteria data include: Education, Teaching, Community Service, Service Orientation, Integrity, Commitment, Discipline, Cooperation, and leadership. The data used is data from the tri dharma college of the lecturer, be it research, learning, and community service data along with a list of employee executive assessments (DP3) of the five lecturers.

The implementation of this program system includes specifications of hardware requirements (hardware), and specifications of software (software). This program is recommended to run using hardware (hardware) that has the following specifications:

1. Intel Pentium Dual Core Process, $2.5 \mathrm{GHz}$

2. Memory $1 \mathrm{~GB}$

3. $80 \mathrm{~GB}$ hard drive

4. $64 \mathrm{MB}$ VGA card

5. Monitor with a resolution of $1024 \times 800$ pixels

6. Keyboard and Mouse

The software or software used to run this application is the Windows Seven Operating System Environment or Windows 10 Application using Web Programing. The steps of processing lecturer performance data using the Lecturer Performance appraisal application using the PHP programming language are carried out in the following manner:

Double-click the Xampp Control Panel Icon on the desktop and open Google Chrome, or Internet Explorer then type in the search page localhost / Kinerja_dosen so that the Admin page of the lecturer performance application will appear and ask for a password.

\section{Dashboard Form}

This form is the homepage or main page which contains Lecturer data, Criteria data, Criteria Set, Lecturer Assessment, Calculation of the final result and Sig Out of the results and information which functions as follows:

a. Home is the home page.

b. Lecturer data input lecturer data such as NIP input, lecturer name, which contains lecturer biodata.

c. Data The input criteria are the criteria data such as the criteria name weight criteria.

d. Criteria set is a menu to display the form results from the weights of our criteria.

e. Lecturer Assessment is a menu for selecting which lecturer data we will input.

f. The calculation is the result of the lecturer assessment process using the topsis method. 


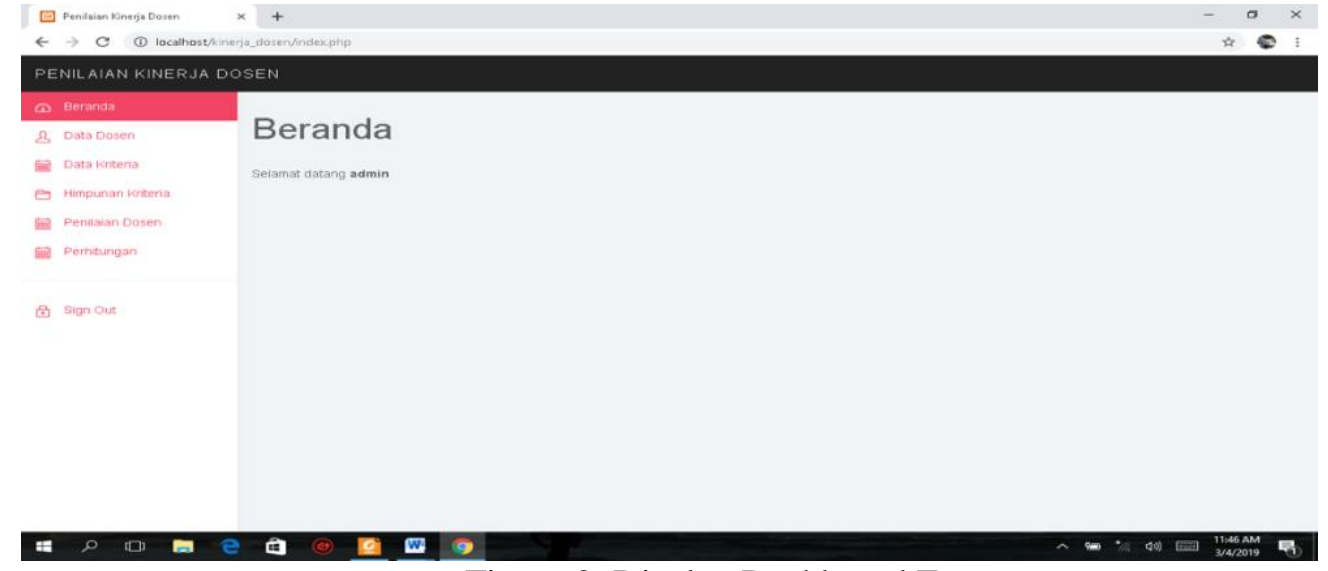

Figure 2. Display Dashboard Form

\section{Add Lecturer Data Page}

Information from Figure 3. The Lecturer Data Input Form consists of 5 fields, namely:

a. NIDN contains the lecturer ID number code.

b. Name containing the name of the lecturer.

c. Address contains the address of the lecturer.

d. Education contains the lecturer education.

e. Position contains the lecturer's position.

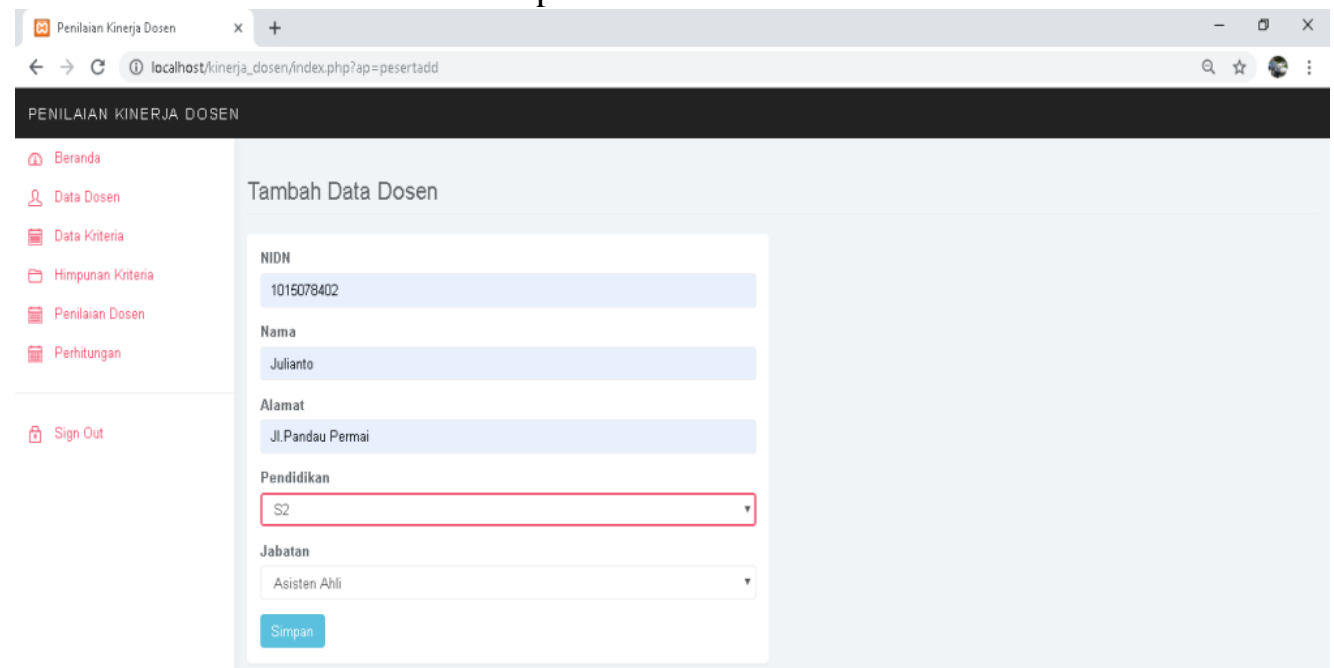

Figure 3. Display Add Lecturer Data

The description of Figure 3 is a display of the inputted lecturer data such as Nip / Nidn, Name, Address, Education and Position, all of which are the result of adding lecturer data or called lecturer master data. 


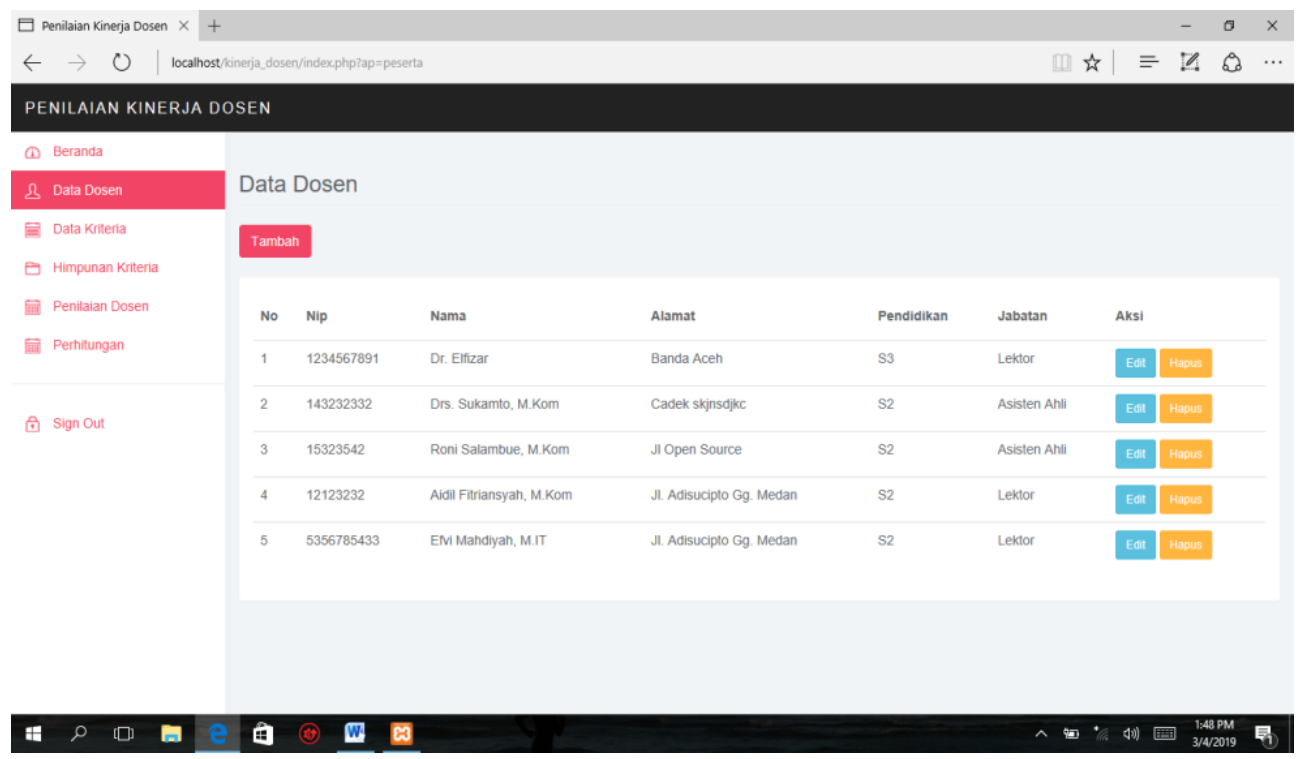

Figure 4. Display of Lecturer Data

The description of Figure 4 is a display of the inputted lecturer data such as Nip / Nidn, Name, Address, Education and Position, all of which are the result of adding lecturer data or called lecturer master data.
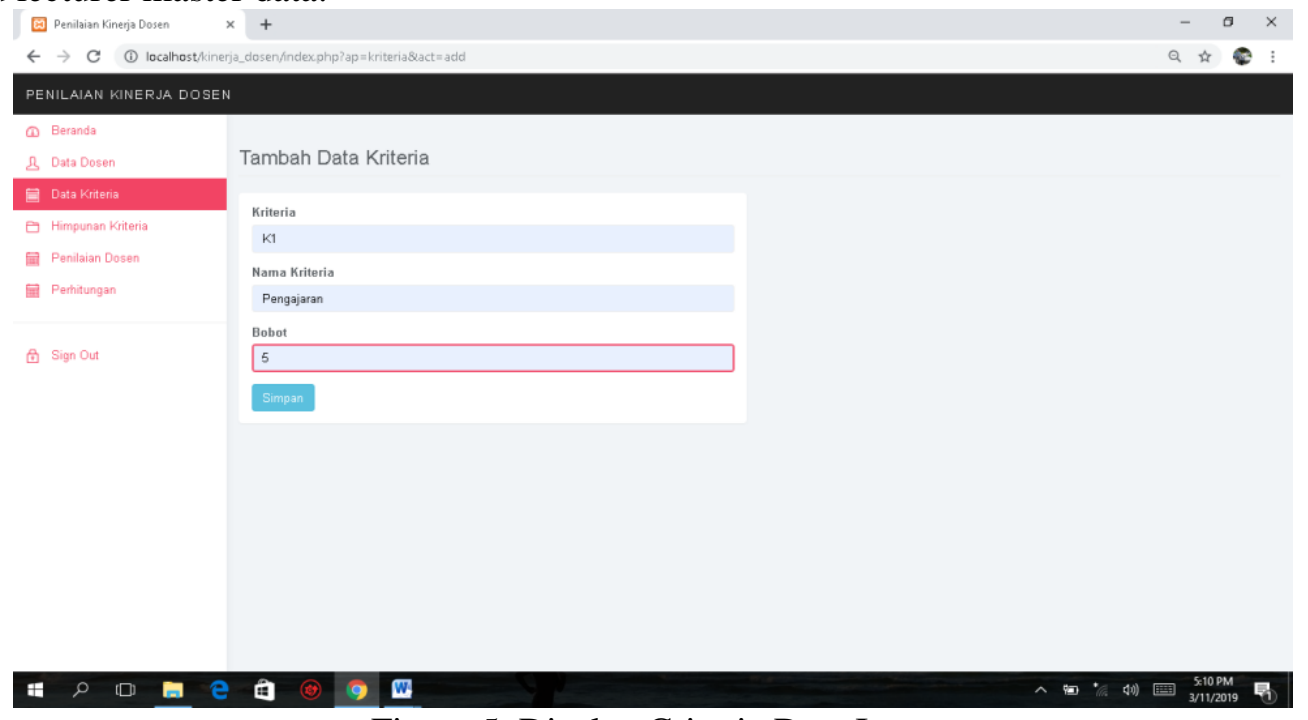

Figure 5. Display Criteria Data Input

The input of the value of the Tridrahma of Higher Education from research to the input of the DP3 value of the lecturer based on the amount that has been processed from the lecturers' data such as the value of teaching, research value and community service. 


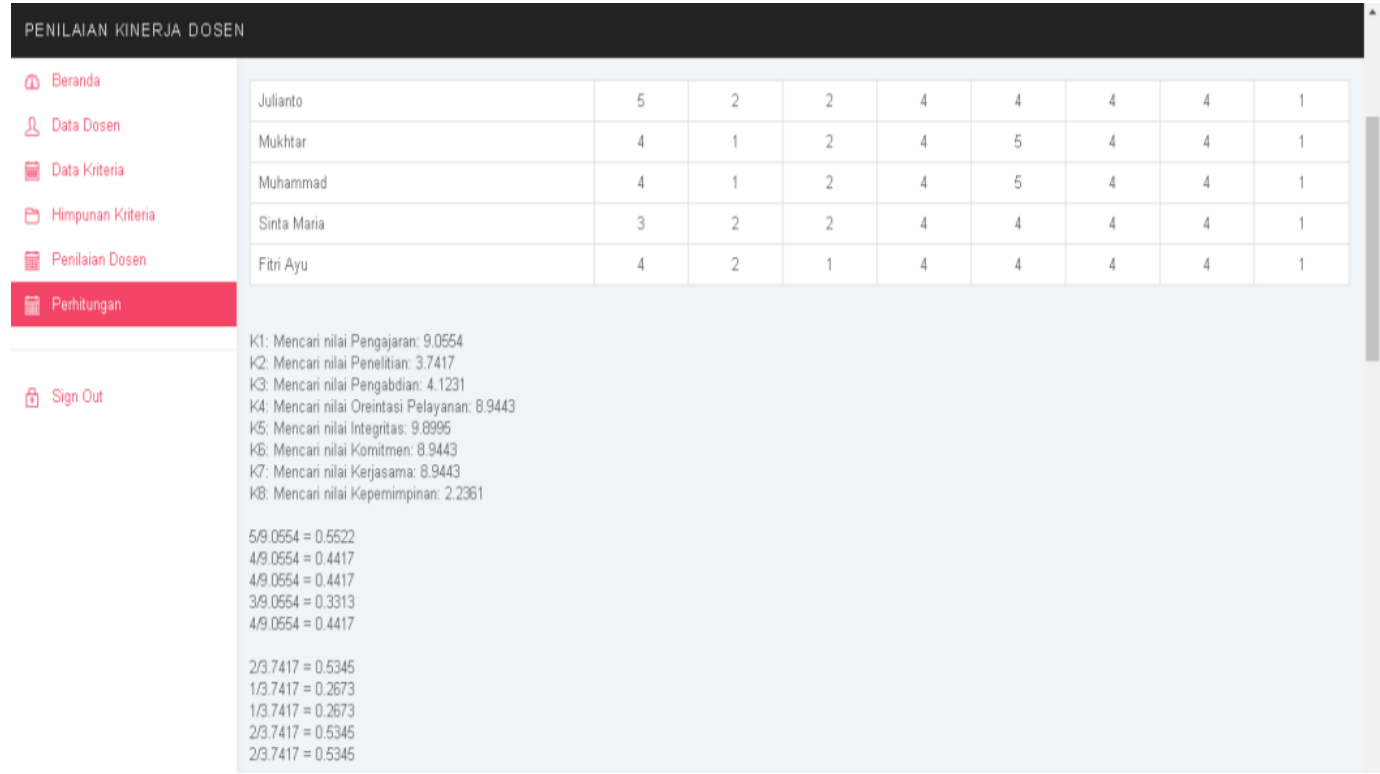

Figure 6. Display of Criteria Value Process Results

This is test results page contains lecturer performance appraisal data can be seen that compares the original manual data with the system data results.

Table 1. Information of Calculation

\begin{tabular}{llllcl}
\hline \multirow{2}{*}{ No } & \multirow{2}{*}{ Lecturer Name } & Original Data & $\begin{array}{c}\text { Result of System } \\
\text { Data }\end{array}$ & year & Accuracy \\
\hline 1 & Julianto & 0.8419 & 0.8467 & 2017 & 99.4331 \\
2 & Mukhtar & 0.4579 & 0.5588 & 2017 & 49.5705 \\
3 & Muhammad & 0.3308 & 0.4935 & 2017 & 67.0314 \\
4 & Sinta Maria & 0.6509 & 0.5218 & 2017 & 80.1659 \\
5 & Fitri Ayu & 0.4932 & 0.5455 & 2017 & 90.4125 \\
\hline
\end{tabular}

To find the level of accuracy in the following ways:

(Sum of Original Data) / (Sum of System Results) X 100\%

1. Julianto lecturer accuracy $=99 \%$

2. Mukhtar lecturer accuracy $=49 \%$

3. Muhammad lecturer accuracy $=67 \%$

4. Sinta Maria lecturer accuracy of $=80 \%$

5. Fitra Ayu lecturer accuracy $=90 \%$

\section{Conclusion}

From the test results it can be concluded that the results are stated right, so that the TOPSIS method can be used by the leadership as a basis for decision making in determining Lecturer Performance Appraisal at Amik Mahaputra Pekanbaru. From the test results, it can be concluded that the results are stated to be correct with an accuracy rate of $74 \%$ so that the TOPSIS method can be used by the leadership as a basis for decision making in determining the assessment of lecturer performance at Amik Mahaputra Pekanbaru. The Technique for Others Reference by Similarity to ideal Solution (TOPSIS) method can be used to rank Lecturer Performance according to predetermined criteria.

\section{References}

Azizu, A. M., \& Sari, W. O. D. P. (2020). The Influence of Competence, Organizational Culture, Spiritual Leadership on Organizational Behavior and Its Impact on Lecturer Performance at Higher Education in Baubau City. International Journal of Management Progress, 1(2), 5072.

Damanik, B., \& Bangun, M. (2018). Evaluasi Kinerja Dosen Univ. Sari Mutiara Indonesia 
Dengan Menggunakan Metode Preference Ranking Organization Method For Enrichment Evaluation (Promethee). Computer Engineering, Science and System Journal, 3(2), 122127.

Hadiantini, R., Prayanta, S., \& Robert, E. (2017). Lecturer performance factors in private universities in Bandung City. International Journal of Human Resource Studies, 7(4), 231239.

Irawan, Y. (2020). Decision Support System For Employee Bonus Determination With WebBased Simple Additive Weighting (SAW) Method In PT. Mayatama Solusindo. Journal of Applied Engineering and Technological Science (JAETS), 2(1), 7-13.

Lubis, A. H., Idrus, S. Z. S., \& Sarji, A. (2018). ICT usage amongst lecturers and its impact towards learning process quality. Jurnal Komunikasi: Malaysian Journal of Communication, 34(1).

Mufizar, T. (2016). Sistem Pendukung Keputusan Pemilihan Dosen Berprestasi Di STMIK Tasikmalaya Menggunakan Metode Simple Additive Weighting (SAW). CSRID (Computer Science Research and Its Development Journal), 7(3), 155-166.

Muslihudin, M., Ilayaraja, M., Kumar, K. S., Shankar, K., Jamilah, J., Novitasari, D., ... \& Maseleno, A. (2019). Decision support system in kindergarten selection using TOPSIS method. International Journal of Recent Technology and Engineering (IJRTE), 8(1).

Rahim, R., Supiyandi, S., Siahaan, A. P. U., Listyorini, T., Utomo, A. P., Triyanto, W. A., ... \& Khairunnisa, K. (2018, June). TOPSIS Method Application for Decision Support System in Internal Control for Selecting Best Employees. In Journal of Physics: Conference Series (Vol. 1028, No. 1, p. 012052). IOP Publishing.

Sari, D. R., Windarto, A. P., Hartama, D., \& Solikhun, S. (2018). Sistem Pendukung Keputusan untuk Rekomendasi Kelulusan Sidang Skripsi Menggunakan Metode AHP-TOPSIS. Jurnal Teknologi dan Sistem Komputer, 6(1), 1-6.

Suryaman, S. (2018). Indonesian Private University Lecturer Performance Improvement Model to Improve a Sustainable Organization Performance. Int. J. High. Educ, 7(1), 59.

Surya, C. (2018). Penilaian Kinerja Dosen Menggunakan Metode TOPSIS (Studi Kasus: AMIK Mitra Gama). JURNAL RESTI (Rekayasa Sistem dan Teknologi Informasi), 2(1), 322-329.

Tahir, M., Haming, M., \& Bijaang, J. (2018). Organizational communication effect on lecturer performance in Muhammadiyah University of Makassar.

Zyoud, S. H., \& Fuchs-Hanusch, D. (2017). A bibliometric-based survey on AHP and TOPSIS techniques. Expert systems with applications, 78, 158-181. 